\title{
Pengaruh Perbandingan Tepung Millet (Panicum milliaceum) Dan Maizena Terhadap Karakteristik Cookies
}

\section{The Comparison Effect of Millet Flour (Panicum milliaceum) and Cornstarch on Cookies Characteristic}

\author{
Lourent Maria $\mathrm{O}^{1}$, I Desak Putu Kartika Pratiwi ${ }^{{ }^{*} \text {, Ni Made Indri Hapsari Arihantana }}{ }^{1}$ \\ Program Studi Teknologi Pangan, Fakultas Teknologi Pertanian, Universitas Udayana \\ Kampus Bukit Jimbaran, Badung-Bali \\ *Penulis korespondensi: I Desak Putu Kartika Pratiwi, Email: kartika.pratiwi@unud.ac.id
}

\begin{abstract}
Cookies are a type of biscuit made from soft dough, high in fat, relatively crunchy when broken and has a solid texture. This research was aimed to find out the ratio effect of millet flour and cornstarch to the characteristic of cookies and to determine the exact ratio between millet flour and cornstarch to produce cookies with the best characteristic. The experimental design used in this research was a Completely Randomized Design with a treatment of ratio between millet flour and cornstasch that consisted of 5 levels: 100\%:0\%; 90\%:10\%; 80\%:20\%; 70\%:30\%; and 60\%:40\%. The treatments were repeated three times to obtain 15 experimental units. The data obtained were analyzed by analisis of variance and if the treatment had a significant effect then followed by duncan's multiple range test. The result of research showed that the ratio between millet flour and cornstarch had a significant effect on water content, crude fiber content, starch content, color, texture, taste and overall acceptance (hedonic test), and texture (scoring test). The ratio 90\%:10\% of millet flour and corn starch had the best characteristic with moisture content of $4,31 \%$, crude fiber content of $2,86 \%$, starch content of $42,92 \%$, color was liked, taste was liked, aroma was liked, texture was liked and crunchy, and overall acceptance was liked.
\end{abstract}

Keywords: cookies characteristic, cornstarch, millet flour

\section{PENDAHULUAN}

Cookies merupakan salah satu jenis biskuit yang dibuat dari adonan lunak,berkadar lemak tinggi,relatif renyah bila dipatahkan dan bertekstur padat (Anonimus,1992). Pada umumnya bahan utama dari cookies adalah terigu dengan penambahan bahan lain yang melalui proses pemanasan dan pencetakan. Akan tetapi dewasa ini, marak dilakukan penggunaan tepung lainya untuk menurunkan ketergantungan terhadap terigu dan juga untuk menghasilkan produk pangan yang bebas gluten.

Tepung millet merupakan alternatif pengganti terigu dalam pembuatan cookies. Tepung millet berasal dari spesies proso millet
(Panicum milliaceum) yaitu salah satu jenis spesies millet yang banyak dikembangkan di Indonesia. Millet memiliki kandungan gizi yang mirip dengan tanaman pangan lainya seperti gandum, padi, jagung, dan tanaman biji-bijian yang lain. Menurut National Nutrient Database (2012) proso millet mengandung protein $11,02 \%$, lemak $4,22 \%$, air $8,67 \%$, abu 3,25\%, dan karbohidrat 72,85\%. Millet sendiri memiliki kelemahan ialah memiliki kandungan zat anti gizi yaitu tanin oleh karena itu pengolahan proso millet menjadi tepung menggunakan metode kecambah-fermentasi dengan tujuan untuk menurunkan kadar tanin dari tepung kecambah millet terfermentasi dari 2,92\% menjadi 0,59\% (Mahendra et al.,2019). Penurunan kadar tanin bertujuan mengurangi rasa pahit yang 
dapat mempengaruhi rasa akhir dari produk. Selanjutnya Mahendra et al. (2019) melaporkan bahwa tepung kecambah millet terfermentasi memiliki kadar air sebesar 12,36\% kadar abu sebesar 1,45\% kapasitas penyerapan air sebesar $172,85 \%$ kapasitas penyerapan minyak sebesar $107,73 \%$, swelling power sebesar 10,11 g/g dan indeks kelarutan air sebesar $44,10 \%$. Pratiwi dan Sugitha (2020) melaporkan tepung kecambah millet terfermentasi memiliki kandungan pati sebesar $69,34 \%$ dan kandungan serat pangan sebesar 12,55\% (bk). Beberapa penelitian telah melaporkan Tepung Kecambah Millet Terfermentasi dalam pengolahan produk pangan seperti flakes, biskuit mpasi, dan snackbar (Malinda et al., 2013; Pratiwi dan Hapsari, 2019; Pratiwi dan Sugitha, 2020). Husein et al (2019) melaporkan cookies $100 \%$ millet memiliki tingkat kekerasan yang rendah dan daya patah tinggi, daya patah cookies $100 \%$ tepung millet lebih tinggi daripada cookies kontrol yang terbuat dari 100\% terigu. Keberhasilan cookies non terigu, didukung oleh adanya kandungan pati dari bahan pengikat. Kandungan pati dari adonan mengalami reaksi biokimia dan fisikokimia selama pemanganggan yang diduga berhubungan dengan sifat gelatinisasi pati (Brennan dan Samyue, 2007). Proporsi antara amilosa dan amilopektin dari pati memberikan efek pati secara fungsional yang berguna dalam pembentukan tekstur dari cookies sehingga membuat struktur cookies menjadi lebih kokoh (Sayangbati et al., 2013). Oleh karena itu, untuk menghasilkan cookies non terigu dengan karakteristik padat dan renyah diperlukan penambahan tepung dengan kandungan amilopektin tinggi untuk memperbaiki tekstur dari cookies millet salah satunya dengan penggunaan maizena. Maizena merupakan pati jagung yang memiliki kandungan pati $86,7 \%$ yang terdiri dari $75 \%$ amilopektin dan 25\% amilosa (Utomo et al., 2017).

Penelitian ini bertujuan untuk mengetahui pengaruh variasi perbandingan tepung millet dengan maizena terhadap karakteristik cookies serta perbandingan tepung millet dengan maizena yang tepat sehingga menghasilkan cookies dengan karakteristik terbaik.

\section{METODE PENELITIAN}

\section{Tempat dan waktu penelitian}

Penelitian ini dilaksanakan di Laboratorium Analisis Pangan dan Laboratorium Pasca Panen, Fakultas Teknologi Pertanian, Universitas Udayana serta Laboratorium Nutrisi dan Makanan ternak, Fakultas Peternakan, Universitas Udayana, Kampus Sudirman, Denpasar. Waktu penelitian ini berlangsung dari Agustus sampai September 2020.

\section{Bahan dan Alat}

Bahan utama yang digunakan dalam pembuatan cookies adalah proso millet yang diperoleh dari Pasar Burung Sanglah, Denpasar, maizena (maizenaku). Bahan tambahan yang digunakan yaitu telur, gula halus (rose brand), susu bubuk (dancow), baking powder (koepokoepo),margarin (blueband cookies) yang diperoleh dari Toko UD Ayu, Denpasar. Bahan kimia yang digunakan dalam melakukan analisis meliputi $\mathrm{H}_{2} \mathrm{SO}_{4}, \mathrm{NaOH} \mathrm{PA}, \mathrm{HCl}$, heksan, alkohol 
$96 \%, \mathrm{NaOH}$ teknis, aquades, anthrone dan indikator pp.

Alat-alat yang digunakan dalam melaksanakan penelitian ini antara lain waskom, timbangan analitik, ayakan 60 mesh, blender, mixer, timbangan digital, kuas untuk ayakan, kompor gas, loyang, oven (denpoo) . Alat yang digunakan untuk analisis sifat fisik dan kimia adalah lumpang, kertas saring, kertas whatman 42 , corong, eksikator, botol timbang, oven, timbangan analitik, aluminium foil, pinset, pipet tetes, pipet volume, labu erlenmeyer, gelas beaker, gelas ukur, destilator, pompa karet, labu takar, tabung reaksi, water bath, spektorofotometer.

\section{Rancangan Penelitian dan analisis data}

Rancangan yang digunakan dalam penelitian ini yaitu Rancangan Acak Lengkap (RAL) dengan perlakuan perbandingan tepung millet dan maizena terdiri dari 5 taraf yaitu : P0 (100\% tepung millet :0\% maizena), P1 (90\% tepung millet: 10\%maizena), P2 (80\% tepung millet: 20\% maizena), P3 (70\% tepung millet: 30\% maizena), P4 (60\% tepung millet: 40\% maizena). Setiap perlakuan diulang sebanyak 3 kali sehingga diperole 15 unit percobaan. . Data yang diperoleh dari hasil penelitian dianalisis dengan sidik ragam atau Analysis of Variance (ANOVA) dan apabila perlakuan berpengaruh terhadap variabel, maka dilanjutkan dengan Duncan Multiple Range Test (DMRT) (Steel dan Torrie, 1993).

\section{Pelaksanaan Penelitian}

Adapun tahap pelaksanaan penelitian ini yaitu:

\section{Pembuatan Tepung Millet}

Berdasarkan penelitian Mahendra et al. (2019) pembuatan tepung milet kecambah terfermentasi dilakukan dengan menggambungkan metode perkecambahan (Dewi et al., 2018) dilanjutkan dengan metode fermentasi (Kindiki et al., 2015). proses pembuatan tepung millet: biji proso millet ditimbang sebanyak $500 \mathrm{~g}$ dan dicuci dengan air hingga bersih, kemudian direndam selama 12 jam. Setelah 12 jam, biji millet ditiriskan, diletakkan pada wadah yang ditutupi kain basah, dan dikecambahkan selama 72 jam. Selama proses perkecambahan, bij millet disiram dengan air $50 \mathrm{ml}$ secara merata setiap $12 \mathrm{jam}$. Biji millet yang telah berkecambah kemudian dicuci dan diletakkan pada wadah steril (toples kaca) dan direndam aquadest steril dengan ratio 1:2 (w/v) dalam keadaan tertutup. Fermentasi spontan secara sub merge dilakukan selama 24 jam. Setelah difermentasi, millet dicuci dengan air mengalir, ditiriskan dan dikeringkan menggunakan ovem, suhu $60^{\circ} \mathrm{C}$ selama $3 \mathrm{jam}$, kemudian dihaluskan menggunakan blender dan diayak menggunakan ayakan 60 mesh.

\section{Pembuatan Cookies}

Bahan yang digunakan untuk pembuatan cookies yaitu tepung millet, maizena, margarin, gula halus, kuning telur, susu bubuk, dan baking powder ditimbang terlebih dahulu sesuai dengan formula pada Tabel 1.

Berdasarkan penelitian (Ekawati et al., 2016) pembuatan cookies dilakukan dengan tahap pencampuran yaitu margarin dan gula halus dikocok dengan mixer dengan kecepatan tinggi 5 menit. Selanjutnya ditambahkan telur, didaduk 
dengan kecepatan tinggi selama 10 menit sampai adonan berwarna kuning pucat. Terakhir ditambahkan susu bubuk, tepung millet, dan maizena sesuai perlakuan, diaduk dengan kecepatan rendah selama 5 menit sampai adonan kalis, didinginkan dalam lemari es selama 15 menit adonan dingin, dicetak dengan panjang $3 \mathrm{~cm}$, tinggi $3 \mathrm{~cm}$, dan lebar $1 \mathrm{~cm}$, dipanggang dalam oven dengan suhu $180^{\circ} \mathrm{C}$ selama 20 menit.

Tabel 1. Formulasi cookies dengan perbandingan tepung millet dan maizena

\begin{tabular}{lcccccc}
\hline \multirow{2}{*}{ No. } & \multirow{2}{*}{ Komposisi Bahan } & \multicolumn{5}{c}{ Perlakuan } \\
\cline { 2 - 6 } & Tepung kecambah millet & 100 & 90 & 80 & 70 & 60 \\
\hline 1 & terfermentasi (g) & 0 & 10 & 20 & 30 & 40 \\
2 & Maizena (g) & 60 & 60 & 60 & 60 & 60 \\
3 & Margarin (g) & 25 & 25 & 25 & 25 & 25 \\
4 & Gula Halus (g) & 50 & 50 & 50 & 50 & 50 \\
5 & Kuning telur (g) & 15 & 15 & 15 & 15 & 15 \\
6 & Susu bubuk (g) & 0,5 & 0,5 & 0,5 & 0,5 & 0,5 \\
7 & Baking Powder(g) & & & & \\
\hline
\end{tabular}

Sumber: Ekawati et al., (2016)

\section{Variabel yang diamati}

Variabel yang diamati pada penelitian ini meliputi kadar air dengan metode pengeringan, kadar serat kasar dengan metode hidrolisis asam basa (Sudarmadji et al.,1997), kadar pati dengan metode anthrone (Apriyantono et al.1989), dan evaluasi sensoris (Soekarto, 1985) yang meliputi uji hedonic terhadap warna, aroma, rasa, tekstur, dan penerimaan keseluruhan, sedangkan uji skoring dilakukan terhadap tekstur.

\section{HASIL DAN PEMBAHASAN}

Berikut adalah nilai rata-rata dari bahan baku cookies millet dapat dilihat pada Tabel 3 .

Tabel 2. Nilai rata-rata kadar air, kadar serat kasar, dan kadar pati bahan baku

\begin{tabular}{ccc}
\hline Komponen & Tepung Millet & Tepung Maizena \\
\hline Kadar Air (\%) & $12,97 \% \pm 0,07 \mathrm{a}$ & $9,87 \% \pm 0,12 \mathrm{~b}$ \\
Kadar Serat Kasar (\%) & $4,00 \% \pm 0,34 \mathrm{a}$ & $0,01 \% \pm 0,04 \mathrm{a}$ \\
Kadar Pati (\%) & $48,98 \% \pm 0,49 \mathrm{~b}$ & $88,07 \% \pm 0,14 \mathrm{~b}$ \\
\hline
\end{tabular}

Tabel 3. Nilai rata-rata kadar air, kadar serat kasar, dan kadar pati cookies

\begin{tabular}{llrl}
\hline $\begin{array}{c}\text { Perlakuan (Tepung } \\
\text { Millet:Maizena) }\end{array}$ & Kadar air (\%) & Kadar serat kasar (\%) & Kadar pati (\%) \\
\hline P0 (100\%:0\%) & $3,66 \pm 0,23 \mathrm{~b}$ & $4,06 \pm 0,54 \mathrm{a}$ & $35,14 \pm 0,80 \mathrm{e}$ \\
P1 (90\%:10\%) & $4,31 \pm 0,07 \mathrm{ab}$ & $2,86 \pm 0,54 \mathrm{~b}$ & $42,92 \pm 0,58 \mathrm{~d}$ \\
P2 (80\%:20\%) & $4,41 \pm 0,73 \mathrm{ab}$ & $2,82 \pm 0,40 \mathrm{~b}$ & $48,92 \pm 0,74 \mathrm{c}$ \\
P3 (70\%:30\%) & $4,85 \pm 0,55 \mathrm{a}$ & $2.78 \pm 0,40 \mathrm{~b}$ & $53,62 \pm 0,64 \mathrm{~b}$ \\
P4 (60\%:40\%) & $5,14 \pm 0,52 \mathrm{a}$ & $2,34 \pm 0,24 \mathrm{~b}$ & $62,81 \pm 0,59 \mathrm{a}$ \\
\hline
\end{tabular}

Keterangan: Nilai rata - rata yang diikuti oleh huruf yang berbeda pada kolom yang sama menunjukkan berbeda nyata $(\mathrm{P}<0,05)$. 


\section{Kadar Air}

Hasil sidik ragam menunjukkan bahwa perbandingan tepung millet dan maizena berpengaruh nyata $(\mathrm{P}<0,05)$ terhadap kadar air cookies yang dihasilkan. Tabel 3 menunjukkan kadar air cookies berkisar antara 3,66\% - 5,14\%. Kadar air terendah diperoleh pada P0 dengan nilai $3,66 \%$ dan tidak berbeda nyata dengan $\mathrm{P} 1$ dan $\mathrm{P} 2$, dan kadar air tertinggi diperoleh pada $\mathrm{P} 4$ dengan nilai 5,14\% dan tidak berbeda $(\mathrm{P}>0,5)$ dengan $\mathrm{P} 1$, P2, dan P3.

Berdasarkan Tabel 3, perbandingan tepung millet dengan maizena pada konsentrasi 60:40 meningkatkan kadar air cookies hal ini disebabkan karena maizena mengandung amilopektin yang tinggi sebesar 75\% (Utomo et al., 2017. Menurut Winarno (2004) semakin kecil kandungan amilosa atau semakin tinggi kandungan amilopektinya, maka pati cenderung menyerap air. Proses pemanasan yang tinggi akan menyebabkan pembengkakan granula pati yang juga diikuti dengan oeningkatan viskositas dimana terjadi penguapan sehingga menyebabkan pori-pori pada adonan lebih banyak terbentuk sehingga kesempatan air masuk kedalam pori-pori semakin tinggi.

\section{Kadar Serat Kasar}

Hasil sidik ragam menunjukkan bahwa perbandingan tepung millet dengan maizena berpengaruh nyata $(\mathrm{P}<0,05)$ terhadap serat kasar cookies yang dihasilkan. Tabel 3 menunjukkan kadar serat kasar cookies berkisar antara 2,34\%$4,06 \%$. Kadar serat tertinggi dihasilkan pada perlakuan P0 sebesar 4,06\%. Kadar serat kasar terendah dihasilkan pada perlakuan P4 sebesar
2,34\% dan tidak berbeda $(\mathrm{P}>0,5)$ dengan perlakuan P1, P2, dan P3.

Berdasarkan Tabel 3, perbandingan tepung millet dengan maizena pada konsentrasi 60:40 menurunkan kadar serat kasar cookies hal ini disebabkan karena kadar serat maizena lebih rendah dibandingkan tepung millet. Kandungan serat pada maizena sebesar $0,01 \%$, sedangkan kandungan serat pada tepung millet sebesar 4,00\%. Hal ini serupa dengan penelitian Yuliana et al. (2020) yang melaporkan penggunaan tepung milet dapat meningkatkan kadar serat donat menjadi $10,27 \%$ dimana donat yang terbuat dari $100 \%$ terigu memiliki kadar serat kasar 3,10\%.

\section{Kadar Pati}

Hasil sidik ragam menunjukkan bahwa perbandingan tepung millet dengan maizena berpengaruh nyata $(\mathrm{P}<0,05)$ terhadap kadar pati cookies yang dihasilkan. Tabel 3. menunjukkan kadar pati pada cookies berkisar antara 35,14\%$62,81 \%$. Kadar pati tertinggi dihasilkan pada perlakuan P4 sebesar 62,81\%. Kadar pati terendah dihasilkan pada perlakuan P0 sebesar 35,14\%. Semakin tinggi konsentrasi maizena yang digunakan maka kadar pati cookies semakin tinggi, hal ini disebabkan oleh kadar pati tepung millet sebesar 48,98\% sedangkan kadar pati maizena sebesar $88,07 \%$. Data tersebut menunjukkan bahwa kadar pati maizena lebih tinggi dibandingkan kadar pati tepung millet.

Maizena merupakan pati jagung. Pati tersusun dari dua macam karbohidrat yakni amilosa dan amilopektin, dalam komposisi yang berbedabeda. Umumnya, pati mengandung lebih banyak amilopektin dibanding dengan kandungan amilosa. 
Pati alami mengandung amilosa sebesar $15 \%$ dan amilopektin sebesar $85 \%$. Kandungan pati pada maizena terdiri dari dua fraksi yang dapat dipisah dengan air panas, yaitu fraksi terlarut disebut amilosa dan fraksi tidak terlarut disebut amilopektin.

\section{Karakteristik Sensoris}

Evaluasi sensoris cookies didapatkan melalui pengujian hedonik dan skoring. Uji hedonik dilakukan terhadap warna, aroma, tekstur, rasa dan penerimaan keseluruhan. Uji skoring dilakukan terhadap tekstur dengan kriteria mutu renyah. Nilai rata-rata uji hedonik terhadap warna, aroma, tekstur, rasa, dan penerimaan keseluruhan cookies dapat dilihat pada Tabel 4. Nilai rata-rata uji skoring terhadap tekstur dapat dilihat pada Tabel 5.

Tabel 4. Nilai rata-rata uji hedonik warna, aroma, tekstur, rasa, dan penerimaan keseluruhan cookies

\begin{tabular}{|c|c|c|c|c|c|}
\hline \multirow{2}{*}{$\begin{array}{l}\text { Perlakuan (Tepung } \\
\text { Millet:Maizena) }\end{array}$} & \multicolumn{5}{|c|}{ Nilai Rata-Rata Uji Hedonik } \\
\hline & Warna & Aroma & Tekstur & Rasa & $\begin{array}{l}\text { Penerimaan } \\
\text { keseluruhan }\end{array}$ \\
\hline $\begin{array}{c}\text { P0 } \\
(100 \%: 0 \%)\end{array}$ & $6,10 \pm 0,71 \mathrm{a}$ & $5,60 \pm 0,75 a$ & $4,95 \pm 1,57 \mathrm{ab}$ & $6,15 \pm 0,74 a$ & $6,00 \pm 0,72 \mathrm{a}$ \\
\hline $\begin{array}{c}\text { P1 } \\
(90 \%: 10 \%)\end{array}$ & $\begin{array}{c}5,50 \pm 1,14 \mathrm{a} \\
\mathrm{b}\end{array}$ & $5,80 \pm 0,41 \mathrm{a}$ & $5,50 \pm 1,14 \mathrm{a}$ & $\begin{array}{c}5,70 \pm 0,73 a \\
b\end{array}$ & $5,65 \pm 0,74 a$ \\
\hline $\begin{array}{c}\mathrm{P} 2 \\
(80 \%: 20 \%)\end{array}$ & $\begin{array}{c}5,95 \pm 0,75 a \\
b\end{array}$ & $5,70 \pm 0,92 \mathrm{a}$ & $5,60 \pm 1,12 \mathrm{a}$ & $\begin{array}{c}5,55 \pm 1,23 a \\
b\end{array}$ & $5,50 \pm 1,27 \mathrm{a}$ \\
\hline $\begin{array}{c}\text { P3 } \\
(70 \%: 30 \%)\end{array}$ & $\begin{array}{c}5,45 \pm 1,19 a \\
b\end{array}$ & $5,60 \pm 0,88 \mathrm{a}$ & $5,05 \pm 1,35 \mathrm{a}$ & $\begin{array}{c}5,05 \pm 1,31 b \\
c\end{array}$ & $5,25 \pm 1,29 a$ \\
\hline $\begin{array}{c}\mathrm{P} 4 \\
(60 \%: 40 \%)\end{array}$ & $5,20 \pm 1,50 \mathrm{~b}$ & $5,25 \pm 1,48 \mathrm{a}$ & $4,15 \pm 1,38 b$ & $4,75 \pm 1,68 \mathrm{c}$ & $4,40 \pm 1,56 b$ \\
\hline
\end{tabular}

Keterangan: Nilai rata - rata yang diikuti oleh huruf yang berbeda pada kolom yang sama menunjukkan berbeda nyata $(\mathrm{P}<0,05)$. kriteria hedonik: 1 (sangat tidak suka); 2(tidak suka); 3(agak tidak suka); 4 (biasa); 5(agak suka); 6(suka); 7(sangat suka)

\section{Tabel 5. Nilai rata-rata uji skoring tekstur}

\begin{tabular}{lc}
\hline Perlakuan (Tepung Millet:Maizena) Tekstur & Nilai Rata-rata Uji Skoring \\
\hline P0 (100\%:0\%) & $3,40 \pm 0,50 \mathrm{~b}$ \\
P1 (90\%:10\%) & $3,95 \pm 0,60 \mathrm{a}$ \\
P2 (80\%:20\%) & $4,00 \pm 0,78 \mathrm{a}$ \\
P3 (70\%:30\%) & $4,10 \pm 0,72 \mathrm{a}$ \\
P4 (60\%:40\%) & $4,20 \pm 0,83 \mathrm{a}$ \\
\hline
\end{tabular}

Keterangan: Nilai rata - rata yang diikuti oleh huruf yang berbeda pada kolom yang sama menunjukkan berbeda nyata $(\mathrm{P}<0,05)$. Kriteria skoring tekstur: 1 (sangat tidak renyah); 2(tidak renyah); 3(agak renyah); 4(renyah); 5(sangat renyah).

\section{Warna}

Hasil sidik ragam menunjukkan bahwa perbandingan tepung millet dan maizena berpengaruh nyata $(\mathrm{P}<0,05)$ terhadap warna cookies. Tabel 4 menunjukkan nilai terendah pada P4 dengan nilai 5,20 (agak suka) dan tidak berbeda dengan perlakuan $\mathrm{P} 1, \mathrm{P} 2$, dan $\mathrm{P} 3$, dan nilai tertinggi diperoleh pada $\mathrm{P0}$ dengan nilai 6,10 
(suka) dan tidak berbeda $(\mathrm{P}>0,05)$ dengan perlakuan P1, P2, dan P3. Berdasarkan hasil penelitian panelis menyukai warna cookies dari perlakuan P0 sampai P2 dengan kriteria suka. Menurut Winarno (2004) warna merupakan komponen yang sangat penting untuk menentukan kualitas atau derajat penerimaan suatu bahan pangan. Suatu bahan pangan meskipun dinilai enak dan teksturnya sangat baik, tetapi memiliki warna yang tidak menarik atau memberi kesan telah menyimpang dari warna yang seharusnya maka bahan tersebut tidak akan dikonsumsi. Penentuan mutu suatu bahan pangan pada umumnya tergantung pada warna karena warna tampil terlebih dahulu.

\section{Aroma}

Hasil sidik ragam menunjukkan bahwa perbandingan tepung millet dengan maizena tidak berpengaruh nyata $(\mathrm{P}>0,05)$ terhadap aroma cookies. Tabel 4 menunjukkan aroma yang dihasilkan pada cookies memiliki kriteria suka . Tingkat perbedaan aroma pada setiap perlakuan cookies disebabkan karena semakin tinggi konsentrasi maizena yang digunakan pada setiap perlakuan. Aroma merupakan faktor yang sangat penting dalam menentukan tingkat penerimaan konsumen, namun sangat sulit dinilai secara obyektif. Hal ini didukung oleh pendapat (Utafiyani, 2018) bahwa uji sensoris pada aroma merupakan sifat sensoris yang paling sulit dikualifikasikan.

\section{Tekstur}

Hasil sidik ragam menunjukkan bahwa perbandingan tepung millet dan maizena berpengaruh nyata $(\mathrm{P}<0,05)$ terhadap tekstur (uji hedonik) dari cookies. Tabel 4 menunjukkan tingkat kesukaan tekstur terendah pada $\mathrm{P} 4$ dengan nilai 4,15 (biasa), dan tingkat kesukaan tertinggi diperoleh P2 dengan nilai 5,60 (suka) dan tidak berbeda $(\mathrm{P}>0,05)$ dengan perlakuan $\mathrm{P} 0, \mathrm{P} 1$, dan P3.

Hasil sidik ragam menunjukkan bahwa perbandingan tepung millet dan maizena berpengaruh nyata $(\mathrm{P}<0,05)$ terhadap uji skoring tekstur. Tabel 5 menunjukkan uji skoring tekstur terendah P0 dengan nilai 3,40 (agak renyah), dan nilai tertinggi diperoleh pada P4 dengan nilai 4,20 (renyah) dan tidak berbeda $(\mathrm{P}>0,05)$ dengan perlakuan P1, P2, dan P3. Perbandingan tepung millet dan maizena dengan konsentrasi 60:40 menghasilkan tekstur cookies semakin renyah. Hal ini didukung oleh pernyataan (Riskiani et al., 2014) bahwa kandungan amilosa yang tinggi pada suatu tepung menghasilkan tekstur pada cookies semakin kompak dan memiliki kerenyahan lebih baik. Hal tersebut menunjukkan bahwa semakin tinggi konsentrasi maizena yang digunakan menghasilkan cookies dengan tekstur renyah.

\section{Rasa}

Hasil sidik ragam menunjukkan bahwa perbandingan tepung millet dengan maizena berpengaruh nyata $(\mathrm{P}<0,05)$, terhadap rasa cookies. Tabel 8 menunjukkan rasa terendah P4 dengan nilai 4,75 (agak suka) dan tidak berbeda $(\mathrm{P}>0,05)$ dengan perlakuan $\mathrm{P} 3$, dan nilai tertinggi diperoleh P0 dengan nilai 6,15 (suka) dan tidak berbeda $(\mathrm{P}>0,05)$ dengan perlakuan $\mathrm{P} 1$, dan $\mathrm{P} 2$. Rasa adalah faktor yang dinilai panelis setelah warna, aroma, dan tekstur yang dapat mempengaruhi penerimaan produk pangan. Rasa 
timbul akibat adanya rangsangan kimiawi yang dapat diterima oleh indera pencicip atau lidah. Rasa yang enak dapat menarik perhatian sehingga konsumen lebih cenderung menyukai makanan dari rasanya (Khasanah, 2003).

\section{Penerimaan Kesuluruhan}

Hasil sidik ragam menunjukkan bahwa perbandingan tepung millet dan maizena berpengaruh nyata $(\mathrm{P}<0,05)$, terhadap penerimaan keseluruhan cookies uji hedonik. Tabel 4 menunjukkan penerimaan keseluruhan (uji hedonik) terendah P4 dengan nilai 4,40 (biasa), dan nilai tertinggi diperoleh P0 dengan nilai 6,00 (suka) dan tidak berbeda $(\mathrm{P}>0,05)$ dengan perlakuan P1, P2, dan P3. Penerimaan keseluruhan dipengaruhi oleh beberapa faktor seperti warna, aroma, tekstur, dan rasa

\section{KESIMPULAN DAN SARAN}

\section{Kesimpulan}

Perbandingan tepung millet dan maizena berpengaruh terhadap kadar air, kadar serat kasar, kadar pati, warna, tekstur, rasa, dan penerimaan kesluruhan. Perbandingan tepung millet $90 \%$ dan maizena10\% menghasilkan cookies dengan karakteristik terbaik dengan kadar air 4,31\%, kadar serat kasar 2,86\%, kadar pati 42,92\%, warna suka, aroma suka, tekstur suka dan renyah, dan penerimaan keseluruhan suka.

\section{Saran}

Berdasarkan hasil penelitian ini disarankan pengolahan cookies menggunakan tepung millet dan maizena sebaiknya menggunakan konsentrasi 90 persen :10 persen, serta dilakukan penelitian lebih lanjut mengenai daya simpan cookies.

\section{DAFTAR PUSTAKA}

Anonimus. (1992). Standar Nasional Indonesia (SNI) 01-2973-1992 tentang Syarat Mutu dan Cara Uji Biskuit. Badan Standarisasi Nasional (BSN). Jakarta.

Apriyantono, A., D. Fardiaz, NL. Puspitasari, Sedarnawati, S. Budiyanto, (1989). Analisis Pangan. PAU Pangan dan Gizi. Bogor.

Badi, S.M. dan R.C. Hoseney. (1976). Use of Sorghum and Pearl Millet Flours in Cookies. Cereal Chemistry 53 (5): 733-738

Brennan, C.S dan E. Samyue. 2007. Evaluation of Starch Degradation and Textural Characteristic of Dietary Fiber Enriched Biscuit. International Journal of Food Properties 3 (7): 647-657.

Ekawati, I.G.A., P.T. Ina, dan ID.P.K. Pratiwi. (2016). Pemanfaatan Limbah Kulit Buah Anggur Menjadi Tepung dan Aplikasinya Pada Pembuatan Biskuit Fungsional. Laporan Usulan Penelitian. Unpublish. Fakultas Teknologi Pertanian. Universitas Udayana.

Gomez, K.A. dan A.A. Gomez. (1995). Prosedur Statistik untuk Penelitian Pertanian. Diterjemahkan oleh: E. Sjamsuddin dan J.S. Baharsjah. UI- Press, Jakarta.

Khasanah, U. (2003). Formulasi Karakterisasi Fisiko-Kimia dan Organoleptik Produk Makanan Sarapan Ubi Jalar (Sweet Potato Flakes). Skripsi. Tidak dipublikasi. Fakultas Teknologi Pertanian. Institut Pertanian Bogor, Bogor.

Kindiki, M.M., A. Onyago dan F. Kyalo. (2015). Effect of Processing on Nutritional and Sensory Quality of Pearl Millet Flour. Food Science and Quality Management 42: 13-19.

Kurniawati, RD. (2006). Penelitian Desain Proses dan Formulasi Optimal Pembuatan Mi Jagung Basah Berbahan Dasar Pati Jagung dan Corn Gluten Meal (CGM). [Skripsi]. Bogor: Institut Pertanian Bogor

Malinda, P. A, R. Baskara Katri. A dan Dian. R. (2013). Kajian Penambahan Tepung Millet Dan Tepung Ubi Jalar Ungu (Ipomoea batatas L.) Sebagai Substitusi Tepung Terigu Pada Pembuatan Flake. Jurnal Teknosains Pangan 2(1) : 39-48.

Mahendra, P. E. Ditya, N. L. A. Yusasrini, dan I. 
D. P. K. Pratiwi. (2019). Pengaruh Metode Pengolahan Terhadap Kandungan Tanin Dan Sifat Fungsional Tepung Proso Millet (Panicum miliaceum). Jurnal ITEPA. 8(4): 354-367.

National Nutrient Database, (2012). Full Report (All Nutrient): 20031, Millet, raw. https://ndb.nal.usda.gov/ndb/food/show/200 31 diakses pada tanggal 14 April 2020.

Pertiwi, S.R.R., I. Kusumaningrum., dan U. Khasanah. (2018). Formulasi Crispy Cookies Berbahan Baku Tepung Kacang Koro Pedang (Canavalia ensiformis) Termodifikasi. Jurnal Agroindustri 4 (1): 68-78

Pratiwi, I.D.P.K dan I.M.Sughita. (2020). Kandungan Tanin dan Serat Pangan dari Tepung Kecambah Millet dan Tepung Kecambah Millet Terfermentasi. Jurnal Ilmiah Teknologi Pertanian, 5(1):34-38.

Pratiwi, I.D.P.K dan N. M. I. Hapsari. (2019). Nilai Protein, B-Karoten Dan Sensoris Biskuit Bayi Dari Tepung Ubi Jalar Kuning Dan Tepung Millet Terfermentasi. Media Ilmiah Teknologi Pangan, 6(1): 66-75.

Riskiani, D., Ishartani, D., \& Affandi, D. R. (2014). Pemanfaatan tepung umbi ganyong (Canna edulis Ker.) sebagai pengganti tepung terigu dalam pembuatan biskuit tinggi energi protein dengan penambahan tepung kacang merah (Phaseolus vulgaris L.). Jurnal Teknosains Pangan, 3(1).

Sayangbati, Frisly., E.J.N Nurali, L. Mandey., dan M.B. Lelembeto. (2013). Karakteristik fisikokimia biskuit berbahan baku tepung pisang goroho (musa acuminate,sp). Jurnal Ilmiah Fakultas Pertanian Universitas Ramtulangi 2 (1).

Sudarmadji, S., B. Haryono, dan Suhardi. (1997). Prosedur Analisis Untuk Bahan Makanan dan Pertanian. Liberty. Yogyakarta.

Soekarto, S.T. (1985). Penilaian Organoleptik (untuk Industri Pangan dan Hasil Pertanian). Penerbit Bharata Karya Aksara, Jakarta.

Utafiyani., Ni, L.A.Y., dan I Gusti, A.E. (2018). Pengaruh Perbandingan Tepung Kacang Hijau (Vigna radiata) dan Terigu Terhadap Karakteristik Bakso Analog. Jurnal ITEPA. 7 (1): 12-22.

Utomo, L., Nuraly Ludong dan Maya. (2017). Pengaruh Penambahan Maizena pada Pembuatan Biskuit Gluten Free Casein Free Berbahan Baku Tepung Pisang Goroho (Musa Acuminate). Jurnal Chemica 1(2)
Wardhani, M. L. A., dan Indriwati, V. (2016). Pengaruh Proporsi Tepung Maizena Dan Puree Rumput Laut Terhadap Kualitas Produk Siomay Ikan Gabus (Opiocephalus Striatus). Jurnal Boga 5(1): 148-157

Wijayanti, A. D. P. M. (2013). Biskuit Tauge Sebagai "Healthy Super Food" Berbasis Sumber Daya Lokal. Menuju Masyarakat Madani Dan Lestari. (1-9). Jogjakarta.

Winarno, F. G. (2004). Hasil-hasil Simposium Penganekaragaman Pangan. Prakarsa Swasta dan Pemda, Jakarta.

Winarti, Sri., dan E. Adi Saputro. (2013). Karakteristik Tepung Prebiotik Umbi Uwi (Dioscorea spp). Jurnal Teknik Kimia $8(1): 17-21$.

Yuliana. (2020).Variasi Perbandingan Terigu dan Tepung Kecambah Millet (Panicum milliaceum) Terfermentasi Terhadap Karakteristik Donat.[Skripsi]. Unpublished. Fakultas Teknologi Pertanian UNUD, Jimbaran. 